\title{
Influence of Varieties and Integrated Nutrient Management on Growth Parameters of Isabgol (Plantago ovata Forsk.) under Northern Dry Zone of Karnataka, India
}

\author{
Siddalingayya V. Salimath", K. N. Kattimani, Y. K. Kotikal, D. R. Patile, \\ Md Jameel Jhalegar, J. Venkatesh and N. S. Nagarja \\ College of Horticulture, Bagalkot \\ University of Horticultural Sciences, Bagalkot-587104, India
}

*Corresponding author

\section{A B S T R A C T}

\section{Keywords}

Vallabh Isabgol-1 and Gujarat

Isabgol-2, Varieties,

INM treatments, varieties with INM, Growth, Yield.

\section{Article Info}

Accepted:

20 August 2019

Available Online:

10 September 2019
The field research was conducted to evaluate the performance of growth parameters of two Isabgol varieties for commercial production in northern dry zone of Karnataka during two years 2015-16 and 2016-17. The experiment was laid out in split plot design (SPD) with sixteen INM treatment combinations at the College of Horticulture, Bagalkot. Among the two Isabgol varieties grown in northern dry zone of Karnataka, analysis of both years with pooled data exhibited higher value was recorded in Vallabh Isabgol-1in growth parameters viz., 50\% early seed germination (5.38), plant height $(36.85 \mathrm{~cm})$, number of leaves per plant $(46.24)$, number of tillers per plant (10.40), leaf area index per plant $\left(33.18 \mathrm{~cm}^{2}\right)$ and seed yield $\left(12.30 \mathrm{q} \mathrm{ha}^{-1}\right)$ as compared to Gujarat Isabgol-2 $\left(11.05 \mathrm{~kg} \mathrm{ha}^{-1}\right)$. Whereas the higher values with INM treatments with respect to plant growth parameters were observed in Viz. $\mathrm{N}_{11}-75 \%$ RD of FYM $\left(7.5 \mathrm{t} \mathrm{ha}^{-1}\right)+75 \%$ RD of NPK $\left(37.5: 18.75: 22.50 \mathrm{~kg} \mathrm{ha}^{-1}\right)+$ Azospirillum $\left(5 \mathrm{~kg} \mathrm{ha}^{-1}\right)+P S B\left(3 \mathrm{~kg} \mathrm{ha}^{-1}\right)+\mathrm{ZnSO}_{4}\left(15 \mathrm{~kg} \mathrm{ha}^{-1}\right)+\mathrm{FeSO}_{4}\left(7.5 \mathrm{~kg} \mathrm{ha}^{-1}\right)$ viz., higher plant height (36.85), number of tillers per plant (13.94).less number of days taken for $50 \%$ seed germination (4.43\%), higher values for interaction effect on growth parameters were recorded in $\mathrm{V}_{1} \mathrm{~N}_{11}$.viz., higher plant height (37.39), number of tillers per plant (10.40), leaf area index (2.74), seed yield (12.30 $\left.\mathrm{q} \mathrm{ha}^{-1}\right)$.

\section{Introduction}

It is an annual herb grown during the rabi season, seed coat is known as Isabgol husk under trade. The swelling property of the seed coat or husk after absorption of water is used in medicine against constipation and gastrointestinal disorders; it is used in food industries for the preparation of ice creams, creams, candy etc.

India is the only country producing maximum produce of Isabgol in the international trade. Country earns on an average $₹ 1168.34$ crores 
annually from its exporter (Department of commerce). It is widely cultivated in north Gujarat (₹1504 Lakhs), adjoining Rajasthan (₹ 25,107Lakhs) and Madya Pradesh over an area of about 1,50,000 ha (Anonymous 2015a) Rajasthan is one of the leading states in India and is mainly grown in Bikaner, Jalor, Jodhpur and Pali districts followed by Gujarat both States- out put valued ₹ 26,611 crores of Isabgol crop (Anonymous 2015b). It produces around 90,000 to $1,00,000$ tonnes of Isabgol every year of which Gujarat accounts for around 22-26 per cent share. The productivity of the crop has remained in the range of 632 $\mathrm{kg}$ to $672 \mathrm{~kg}$ per hectare in the state.

In Karnataka, Isabgol cultivation is very meager and only local cultivars are grown with poor yield. There is a wide yield gap between local cultivars and high yielding varieties. Performance of any crop or variety depends upon inherent genetic makeup and its potential, then response to climatic condition of this zone. To attain increased productivity, studies on INM have been carried out with an aim to identify suitable cultivar.

\section{Materials and Methods}

The experiment was conducted in the field at Department of Plantation Spices Medicinal and Aromatic Plants, College of Horticulture, Bagalkot at Haveli farm during the years 2015-16 and 2016-17. Geographically, this experimental site lies in Northern Dry Zone (Zone-3) of Karnataka state in the agroclimatic zone of Karnataka, situated at $16^{\circ}$ North latitude and $74^{\circ} 59^{\prime}$ East longitude and at an altitude of $533.0 \mathrm{~m}$ above mean sea level

The soil of experimental field was red clay loamy in texture, with percentages of sand 22.60 , silt 26.10 and clay52.20 bulk density 1.25 , EC $0.24 \mathrm{dS} \mathrm{m}^{-1}$ and $\mathrm{pH} 8.22$ (alkaline in reaction) with organic carbon 1.63 and available 268.02, 34.80, 273.69 NPK kg ha-1.
The source of seed collection was DMAPR Anandh Gujarat i.e. Vallabh Isabgol-1 $\left(\mathrm{V}_{1}\right)$ and Gujarat Isabgol-2 $\left(\mathrm{V}_{2}\right)$. Seed were sown in 18 November 2015 and 2016 with gross plot size of $3.6 \mathrm{~m} \mathrm{x} 1.5 \mathrm{~m}=5.40 \mathrm{~m}^{2}$ in split plot design in sixteen INM sub treatments with three replications as subplot listed below.

$\mathbf{N}_{1}$-RDF FYM (10 $\left.\mathrm{t} \mathrm{ha}^{-1}\right)+$ RDF NPK $\left(50: 25: 30 \mathrm{~kg} \mathrm{ha}^{-1}\right)$

$\mathbf{N}_{2}$-RDF FYM (10 $\left.\mathrm{t} \mathrm{ha}^{-1}\right)+$ RDF NPK $\left(50: 25: 30 \mathrm{~kg} \mathrm{ha}^{-1}\right)+\mathrm{ZnSo}_{4}\left(15 \mathrm{~kg} \mathrm{ha}^{-1}\right)$

$\mathbf{N}_{3}$-RDF FYM (10 $\left.\mathrm{t} \mathrm{ha}^{-1}\right)+$ RDF NPK $\left(50: 25: 30 \mathrm{~kg} \mathrm{ha}^{-1}\right)+\mathrm{FeSo}_{4}\left(7.5 \mathrm{~kg} \mathrm{ha}^{-1}\right)$

$\mathbf{N}_{4}$-RDF FYM (10 $\left.\mathrm{t} \mathrm{ha}^{-1}\right)+$ RDF NPK $\left(50: 25: 30 \mathrm{~kg} \mathrm{ha}{ }^{-1}\right)+\mathrm{FeSo}_{4}\left(7.5 \mathrm{~kg} \mathrm{ha}^{-1}\right)+$ $\mathrm{ZnSo}_{4}\left(15 \mathrm{~kg} \mathrm{ha}^{-1}\right)$

$\mathbf{N}_{5}$-Vermicompost $\left(1 \mathrm{t} \mathrm{ha} \mathrm{ha}^{-1}\right)+$ RDF NPK $\left(50: 25: 30 \mathrm{~kg} \mathrm{ha}^{-1}\right)$

$\mathbf{N}_{6}$-Vermicompost $\left(1 \mathrm{t} \mathrm{ha}{ }^{-1}\right)+50 \%$ RDF NPK $\left(50: 25: 30 \mathrm{~kg} \mathrm{ha}^{-1}\right)+$ Azospirillum $\left(5 \mathrm{~kg} \mathrm{ha}^{-1}\right)+$ Azotobacter $\left(5 \mathrm{~kg} \mathrm{ha}^{-1}\right)$

$\mathbf{N}_{7}-75 \%$ RD FYM (7.5 $\left.\mathrm{t} \mathrm{ha}^{-1}\right)+75 \%$ RDF NPK (37.5:18.75:22.50 kg ha-1)

$\mathbf{N}_{8}-75 \%$ RD FYM $\left(7.5 \mathrm{t} \mathrm{ha}^{-1}\right)+75 \%$ RDF NPK $\quad\left(37.5: 18.75: 22.50 \quad \mathrm{~kg} \quad \mathrm{ha}^{-1}\right) \quad+$ Azotobacter $\left(5 \mathrm{~kg} \mathrm{ha}^{-1}\right)$

$\mathbf{N}_{9}-75 \%$ RD FYM (7.5 $\left.\mathrm{t} \mathrm{ha}^{-1}\right)+75 \%$ RDF NPK (37.5:18.75:22.50 kg ha $\left.{ }^{-1}\right)+$ Azospirillum $\left(5 \mathrm{~kg} \mathrm{ha}^{-1}\right)$

$\mathbf{N}_{10-75 \%}$ RD FYM (7.5 $\left.\mathrm{t} \mathrm{ha}^{-1}\right)+75 \%$ RDF NPK $\left(37.5: 18.75: 22.50 \mathrm{~kg} \mathrm{ha}^{-1}\right)+P S B(3 \mathrm{~kg}$ $\left.\mathrm{ha}^{-1}\right)$

$\mathbf{N}_{11}-75 \%$ RDF FYM $\left(7.5\right.$ tha $\left.^{-1}\right)+75 \%$ RDF NPK $\left(37.5: 18.75: 22.50 \mathrm{~kg} \mathrm{ha}^{-1}\right)+$ Azospirillum $\left(5 \mathrm{~kg} \mathrm{ha}^{-1}\right)+P S B\left(3 \mathrm{~kg} \mathrm{ha}^{-1}\right)+\mathrm{ZnSo}_{4}(15 \mathrm{~kg}$ ha $=-$ 1) $+\mathrm{FeSo}_{4}\left(7.5 \mathrm{~kg} \mathrm{ha}^{-1}\right)$

$\mathbf{N}_{12}-50 \%$ RDF FYM $\left(5 \mathrm{tha}^{-1}\right)+50 \%$ RDF NPK (25:12.5:15 NPK kg ha ${ }^{-1}$ )

$\mathbf{N}_{13}-50 \%$ RD FYM (5t ha $\left.{ }^{-1}\right)+50 \%$ RDF NPK $\left(25: 12.5: 15 \mathrm{~kg} \mathrm{ha}^{-1}\right)+$ Azotobacter $\left(5 \mathrm{~kg} \mathrm{ha}^{-1}\right)$

$\mathbf{N}_{14-50 \%}$ RDF FYM $\left(5 \mathrm{tha}^{-1}\right)+50 \%$ RDF NPK $\left(25: 12.5: 15 \mathrm{~kg} \mathrm{ha}^{-1}\right)+$ Azospirillum $\left(5 \mathrm{~kg} \mathrm{ha}^{-1}\right)$

$\mathbf{N}_{15-50 \%}$ RD FYM (5t ha $\left.{ }^{-1}\right)+50 \%$ RDF NPK $\left(25: 12.5: 15 \mathrm{~kg} \mathrm{ha}^{-1}\right)+P S B\left(3 \mathrm{~kg} \mathrm{ha}^{-1}\right)$

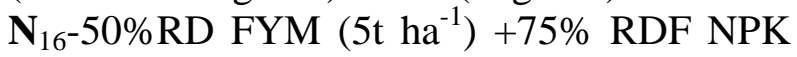


(37.5:18.75:22.50 kg ha-1) + Azospirillum $(5 \mathrm{~kg}$ $\left.\mathrm{ha}^{-1}\right)+P S B \quad\left(3 \mathrm{~kg} \mathrm{ha}^{-1}\right)+\mathrm{Znso}_{4} \quad\left(15 \mathrm{~kg} \mathrm{ha}^{-}\right.$ $\left.{ }^{1}\right)+\mathrm{FeSo}_{4}\left(7.5 \mathrm{~kg} \mathrm{ha}^{-1}\right)$

The experiment after layout then treatments were applied as per above nutrient combination, then mixed thoroughly in plots before imposing the treatments. Zinc was applied in the form of $\mathrm{ZnSO}_{4}$ at the time of sowing half dose of $\mathrm{N}$ was applied as a basal and remaining half was applied one month after sowing as top dressing full dose of $\mathrm{P}$ and $\mathrm{K}$ were applied at the time of sowing below the seed in furrows made with the help of land hoe. Manual thinning weeding and hoeing were done at one month after sowing to provide an ideal environment to the crop a light irrigation was given immediately before sowing, however six and seven irrigation were given as per crop requirement with the help of sprinkler.

Five plants were selected randomly in each plot, number of days taken for 50 per cent seed germination, plant height $(\mathrm{cm})$ and number of tillers per plant and seed yield $(\mathrm{kg}$ $\operatorname{plot}^{-1}$ ) and later calculated it as an seed yield $\left(\mathrm{q} \mathrm{ha}{ }^{-1}\right)$ were analysis the mean values of all the observations were worked out.

\section{Results and Discussion}

At harvest stage growth parameters were significantly higher viz., early $50 \%$ of seed germination (5.19,5.57 and 5.38), plant height $(33.07,33.28 \& 36.60 \mathrm{~cm})$, number of leaves per plant (46.01, $46.48 \& 46.24)$, tillers per plant $(10.30,10.49 \& 10.40)$, leaf area index $(2.68,2.81, \& 2.74)$ and seed yield (12.21, $12.38 \& 12.40 \mathrm{q} \mathrm{ha}^{-1}$ ) during 2015, 2016 and pooled data respectively, may be due to higher quantity of FYM application and bio fertilizers treatment resulting in to early seed germination. Similar findings also reported by Dubey et al., (2009) and Ghaderi-Far et al., (2012). This results due to varietal performance to different agroclimatic conditions and genetical characteristics of particular variety and their difference in genotypic factor and adaptability of particular variety to soil and climatic conditions and the increased number of leaves, leaf area and number of tillers helped in better synthesis of carbohydrates and their utilization for build up of new cells, apart from better absorption of nutrients resulting in increased dry matter production were reported by several workers (Kumar et al., 2009, Shirvan et al., 2016a and Tyagi et al., 2016). and more number of days taken for $50 \%$ seed germination (7.21, 7.44and 7.32), lowest plant height (32.52, $32.11 \& 32.31 \mathrm{~cm}$ ), number of leaves (45.67, $45.63 \& 45.65)$, number of tillers per plant $(10.27,10.43 \& 10.35)$, leaf area index $(2.56$, $2.72 \& 2.74)$ and seed yield (11.02, 11.08 $\& 11.05 \mathrm{q} \mathrm{ha}^{-1}$ ) during 2015, 2016 respectively and pooled data as compared to Gujarat Isabgol-2.

The seed germination was significantly influenced by integrated nutrient management with application of $75 \%$ RD of FYM $+75 \%$ $\mathrm{RD}$ of NPK + Azospirillum $+P S B+\mathrm{ZnSO}_{4}+$ $\mathrm{FeSO}_{4}\left(\mathrm{~N}_{11}\right)(4.50)$ which was on par with $\mathrm{N}_{11}(4.50), \mathrm{N}_{4}$ (4.70)and $\mathrm{N}_{6}(5.09)$, shown early seed germination as compared to all other treatments.

This was influence of favourable soil conditions ( $\mathrm{pH} 8.25$, Electric conductivity 0.27 and organic carbon 1.89) with higher quantity of FYM application and bio fertilizers treatment resulting in to early seed germination. Similar findings also reported by Dubey et al., (2009) and Ghaderi-Far et al., (2012) observed early seed germination was because of alkaline $\mathrm{pH}$ (7-9) with less soil and air temperature $\left(20^{\circ} \mathrm{C}\right)$. Further, the maximum EC was recorded with application of $P S B$ found to be beneficial in early $50 \%$ germination seed vigour by release of growth promoting substances (Sharma et al., 2007). 
Significantly higher plant height at harvest stage in pooled analysis were presented 36.85 $\mathrm{cm}$ was recorded in $\mathrm{N}_{11}$ (75\% RDF FYM + 75 $\% \mathrm{RDF} \mathrm{NPK}+$ Azospirillum $+\mathrm{PSB}+\mathrm{ZnSO}_{4}+$ $\mathrm{FeSO}_{4}$ ), which were on par with $\mathrm{N}_{6}$ (Vermicompost $+50 \%$ RDF NPK + Azospirillum + Azatobacter) (36.85) and $\mathrm{N}_{4}$ $\left(\mathrm{RDF} F Y M+\mathrm{RDF} \mathrm{NPK}+\mathrm{ZnSO}_{4}+\mathrm{FeSO}_{4}\right)$ (35.75), $\mathrm{N}_{16}$ (50\% RDF FYM+ 75\% RDF $\mathrm{NPK}+$ Azospirillum $+P S B+\mathrm{ZnSO}_{4}+$ $\left.\mathrm{FeSO}_{4}\right),(36.42 \mathrm{~cm})$ with the best treatment $\mathrm{N}_{11}$ respectively. Further lower plant height $(29.55 \mathrm{~cm})$ was recorded in $\mathrm{N}_{13}(50 \% \mathrm{RDF}$ $\mathrm{FYM}+50 \% \mathrm{RD}$ of $\mathrm{NPK}+$ Azatobacter) during pooled data, which could be attributed to adequate and balanced nutrients supply by use of organic manures helps faster rate of inorganic nutrients taken by plants towards production of bio-active substances which are having similar effect as that of growth regulators further increased plant growth parameters.

The number of leaves per plant was significantly influenced by integrated nutrient management at harvest stage the higher number of leaves per plant (55.50) was recorded in $\mathrm{N}_{11}$, which was on par with $\mathrm{N}_{4}$ (54.29), $\mathrm{N}_{6}$ (54.24), and $\mathrm{N}_{16}$ (54.06). Further the lower number of leaves per plant was recorded in $\mathrm{N}_{13}$ (37.80). This is because of combined application of nutrients resulted creation of favourable environment for uptake of nutrients for plants by use organic and inorganic nutrients along with Azospirillum and $P S B$ around rhizosphere which attributed to the enhanced the availability nutrients at appropriate time leads to the production of growth promoting substances, further that might have caused cell elongation and multiplication then to increase in the chlorophyll content of leaves resulted in increased synthesis of carbohydrates Yadav et al., (2003).
The significantly higher number of tillers per plant at all the stages of crop growth, at harvest (13.94) was recorded in $\mathrm{N}_{11}$ which was on par with $\mathrm{N}_{4}$ (13.29), $\mathrm{N}_{16}$ (13.27) and $\mathrm{N}_{6}$ (13.20). The significantly lower number of tillers per plant was recorded in $\mathrm{N}_{13}$ (8.48). This has been the consequence as a result of higher nutrient availability with application of organic manure (FYM, VC and biofertilizers) along with inorganic fertilizers which had profound influence in mobilizing the nutrients from the unavailable form of nutrients to available source and also enhanced improvement of soil physical, chemical and biological properties. The micro nutrient zinc application along with organics it acts as a component of carbonic anhydrase, as well as several dehydrogenases and required for auxin production which in turn enhance plant growth. Iron was necessary for the biosynthesis of chlorophyll and cytochrome, leading to increase in photosynthesis processes, respiration, other biochemical physiological activities of the plants. Similar results observed by Salmasi et al., (2012) and Tripathi et al., (2013).

The significantly higher leaf area index at harvest stage (3.43) was recorded in $\mathrm{N}_{11}(75 \%$ $\mathrm{RD}$ of $\mathrm{FYM}+75 \% \mathrm{RD}$ of $\mathrm{NPK}+$ Azospirillum $+P S B+\mathrm{ZnSO}_{4}+\mathrm{FeSO}_{4}$ ) which was on par with $\mathrm{N}_{16}$ (3.34), $\mathrm{N}_{6}$ (3.31), $\mathrm{N}_{4}$ (3.22) and further lower LAI (2.26) was recorded in $\mathrm{N}_{13}$.

This might be due to the production of more number of leaves and green leaf surface leads to in the greater interceptions of light radiation. INM then have resulted increased plant height, tillers per plant results to maximum variation in growth characters then decrease in LAI towards maturity stage findings reported by Patel and Saravanan (2010). 
In INM effect significantly higher seed yield (15.43 q ha ${ }^{-1}$ ) was recorded in supplied of $\mathrm{N}_{11}$ (75 \% RD of FYM $+75 \%$ of RD NPK + Azospirillum $\left.+P S B+\mathrm{ZnSO}_{4}+\mathrm{FeSO}_{4}\right)$, which was on par with $\mathrm{N}_{4}\left(15.12 \mathrm{q} \mathrm{ha}^{-1}\right), \mathrm{N}_{16}(14.90 \mathrm{q}$ $\left.\mathrm{ha}^{-1}\right), \mathrm{N}_{6}\left(14.83 \mathrm{q} \mathrm{ha}^{-1}\right)$. The lower seed yield $\mathrm{N}_{13}\left(9.25 \mathrm{q} \mathrm{ha}^{-1}\right)$. The increased seed yield consequence with application of balanced nutrient RD of FYM $75 \%+$ RD of NPK micro nutrients mixed with bio fertilizers like azospirillum mechanism through phosphate dissolution and in the biosynthesis of bioactive in soil. The biofertilizers help in fixation of atmospheric nitrogen, better root proliferation, better availability and absorption of nutrients by the plants, which might have resulted in better growth in plant further $\mathrm{N} \mathrm{P}$ $\mathrm{K}$ nutrients available form would attributed to more uptake of nutrients in faster rate in plant, $P S B$ helps in reducing phosphorus fixation by its chelating effect and also solubilized the fixed phosphorus accelerated increase in growth of parameters towards reproductive parameters which accelerating tillers, dry matter production and increase towards yield attributing characters viz. number of seeds per spike and more, ultimately all these growth parameters leads to increase seed yield, Similar findings observed by Repsiene (2001), Yadav et al., (2003), Nadim et al., (2011), Singh et al., (2011), Tripati et al., (2013), Choudhary et al., (2014), Nadukeri et al., (2014) and Shivran et al., (2015).

\section{Interaction effect}

Significantly higher plant height at harvest stage $(37.39 \mathrm{~cm})$ was recorded with Vallabh Isabgol-1 supplied with $75 \%$ RD of FYM + $75 \%$ RD of NPK + Azospirillum + PSB+ $\mathrm{ZnSO}_{4}+\mathrm{FeSO}_{4}\left(\mathrm{~N}_{11}\right)$, which was on par with $\begin{array}{llll}\mathrm{V}_{1} \mathrm{~N}_{16} & (36.60 & \mathrm{cm}), & \mathrm{V}_{1} \mathrm{~N}_{6}\end{array}$ (36.57cm), $\mathrm{V}_{2} \mathrm{~N}_{11}(36.32), \mathrm{V}_{2} \mathrm{~N}_{16}(36.23), \mathrm{V}_{1} \mathrm{~N}_{4}$ (35.86). The lower plant height $(28.66 \mathrm{~cm})$ was recorded in $\mathrm{V}_{1} \mathrm{~N}_{13}$ during the pooled data.
The number of leaves per plant was significantly at harvest stage of crop higher number leaves per plant (55.87) was recorded with Vallabh Isabgol-1 supplied with $75 \%$ $\mathrm{RD}$ of $\mathrm{FYM}+75 \% \mathrm{RD}$ of $\mathrm{NPK}+$ Azospirillum $+P S B_{+} \mathrm{ZnSO}_{4}+\mathrm{FeSO}_{4}\left(\mathrm{~V}_{1} \mathrm{~N}_{11}\right)$ which was onpar with $\mathrm{V}_{2} \mathrm{~N}_{11}(55.13), \mathrm{V}_{1} \mathrm{~N}_{6}$ (54.54), $\quad \mathrm{V}_{2} \mathrm{~N}_{16} \quad$ (54.49) and $\quad \mathrm{V}_{1} \mathrm{~N}_{4}$ (54.48), $\mathrm{V}_{1} \mathrm{~N}_{16}$ (53,63), Further the lowest number of leaves per plant was recorded in $\mathrm{V}_{1} \mathrm{~N}_{13}$ (37.40) during the pooled data.

The interaction effect at harvest stage significantly higher number of tillers per plant (14.41) was recorded in $\left(\mathrm{V}_{1} \mathrm{~N}_{11}\right)$ Vallabh Isabgol-1, supplied with (75\% RD of FYM + $\mathrm{RD}$ of NPK + Azospirillum $+P S B+\mathrm{ZnSO}_{4}+$ $\mathrm{FeSO}_{4}$ ) which was on par with $\mathrm{V}_{2} \mathrm{~N}_{16}(13.87)$ followed by $\mathrm{V}_{1} \mathrm{~N}_{6}(13.17), \mathrm{V}_{1} \mathrm{~N}_{4}$ (12.97) where as minimum number of tillers per plant (8.08) was recorded in $\mathrm{V}_{1} \mathrm{~N}_{13}$ during the pooled data. due to Vallabh Isabgol-1 variety and their performance under the agroclimatic condition with application above $75 \%$ RD organic and inorganic NPK fertilizers along secondary nutrients, biofertilizers combined application might resulted plants to more nutrients utilization for plant growth towards production of bio-active substances in soil micro flora, combined use of Azotobacter in soil it acts like growth regulators effects supports the hypothesis through the production of phytohormones, which stimulate root growth in Isabgol increased due to synthesis of carbohydrates, further utilized in building up of new cells towards the production of higher plant height and number of leaves increased tillers per plant which had positive effect towards higher growth parameters plant height, number of leaves, LAI and tiller per plant. Similar results are conformed by Yadav et al., (2003), Venkatesh (2007), Nadim et al., (2011), Mirshekari and Forouzandeh (2015) and Shivran et al., (2016 b). 
Table.1 Growth parameters on plant height $(\mathrm{cm})$, number of leaves per plant and number of tillers per plant as influenced by Isabgol varieties and integrated nutrient management

\begin{tabular}{|c|c|c|c|c|c|c|c|c|c|c|c|c|c|c|c|c|c|c|c|c|c|c|c|c|c|c|c|}
\hline \multirow{3}{*}{$\begin{array}{l}\text { Varieties } \\
\text { Nutrients } \\
\text { Nutrients }\end{array}$} & \multicolumn{9}{|c|}{ Number of day 50per cent seed germination } & \multicolumn{9}{|c|}{ plant height $(\mathrm{cm})$ at harvest } & \multicolumn{9}{|c|}{ Number of leaves per plant at harvest } \\
\hline & \multicolumn{3}{|c|}{2015} & \multicolumn{3}{|c|}{2016} & \multicolumn{3}{|c|}{ Pooled data } & \multicolumn{3}{|c|}{2015} & \multicolumn{3}{|c|}{2016} & \multicolumn{3}{|c|}{ Pooled data } & \multicolumn{3}{|c|}{2015} & \multicolumn{3}{|c|}{2016} & \multicolumn{3}{|c|}{ Pooled data } \\
\hline & $\mathrm{V}_{1}$ & $\mathbf{V}_{2}$ & Mean & $V_{1}$ & $\mathbf{V}_{2}$ & Mean & $V_{1}$ & $\mathbf{V}_{2}$ & Mean & $V_{1}$ & $\mathbf{V}_{2}$ & Mean & $V_{1}$ & $\mathbf{V}_{2}$ & Mean & $V_{1}$ & $\mathbf{V}_{2}$ & Mean & $V_{1}$ & $\mathbf{V}_{2}$ & Mean & $\mathbf{V}_{1}$ & $\mathbf{V}_{2}$ & Mean & $V_{1}$ & $\mathbf{V}_{2}$ & Mean \\
\hline $\mathbf{N}_{1}$ & 5.86 & 6.25 & 6.05 & 6.20 & 7.71 & 6.95 & 6.03 & 6.98 & 6.50 & 31.48 & 30.66 & 31.07 & 32.05 & 30.87 & 31.46 & 31.77 & 30.76 & 31.27 & 46.51 & 49.00 & 47.76 & 47.67 & 49.00 & 48.33 & 47.09 & 49.00 & 48.04 \\
\hline $\mathbf{N}_{2}$ & 5.89 & 6.34 & 6.12 & 5.76 & 7.24 & 6.50 & 5.83 & 6.79 & 6.31 & 32.94 & 31.20 & 32.07 & 31.87 & 31.47 & 31.67 & 32.40 & 31.34 & 31.87 & 44.35 & 48.73 & 46.54 & 45.13 & 48.73 & 46.93 & 44.74 & 48.73 & 46.74 \\
\hline $\mathbf{N}_{3}$ & 4.82 & 5.15 & 4.99 & 5.59 & 6.92 & 6.26 & 5.21 & 6.04 & 5.62 & 30.92 & 29.89 & 30.40 & 31.07 & 30.67 & 30.87 & 30.99 & 30.28 & 30.64 & 44.33 & 48.73 & 46.53 & 45.00 & 48.73 & 46.87 & 44.67 & 48.73 & 46.70 \\
\hline $\mathbf{N}_{4}$ & 4.35 & 4.81 & 4.58 & 4.81 & 4.85 & 4.83 & 4.58 & 4.83 & 4.70 & 35.93 & 35.47 & 35.70 & 35.78 & 35.80 & 35.79 & 35.86 & 35.64 & 35.75 & 53.27 & 54.93 & 54.10 & $\mathbf{5 5 . 7 0}$ & 53.27 & 54.48 & 54.48 & 54.10 & 54.29 \\
\hline $\mathbf{N}_{5}$ & 4.27 & 5.49 & 4.88 & 5.29 & 6.67 & 5.98 & 4.78 & 6.08 & 5.43 & 32.36 & 34.00 & 33.18 & 31.38 & 31.40 & 31.39 & 31.87 & 32.70 & 32.29 & 44.65 & 49.53 & 47.09 & 45.87 & 50.20 & 48.03 & 45.26 & 49.87 & 47.56 \\
\hline$N_{6}$ & 4.40 & 4.90 & 4.65 & 5.76 & 5.28 & 5.52 & 5.08 & 5.09 & 5.09 & 36.68 & 34.92 & 35.80 & 36.47 & 36.23 & 36.35 & 36.57 & 35.58 & 36.07 & 54.00 & 54.47 & 54.24 & 55.08 & 53.41 & 54.25 & 54.54 & 53.94 & 54.24 \\
\hline $\mathbf{N}_{7}$ & 5.82 & 6.63 & 6.22 & 5.84 & 7.23 & 6.54 & 5.83 & 6.93 & 6.38 & 33.33 & 31.40 & 32.36 & 32.53 & 30.90 & 31.72 & 32.93 & 31.15 & 32.04 & 46.13 & 39.33 & 42.73 & 40.47 & 39.33 & 39.90 & 43.30 & 39.33 & 41.32 \\
\hline $\mathbf{N}_{8}$ & 5.64 & 6.16 & 5.90 & 5.65 & 6.62 & 6.14 & 5.65 & 6.39 & 6.02 & 33.01 & 31.01 & 32.01 & 33.37 & 30.60 & 31.98 & 33.19 & 30.80 & 32.00 & 44.27 & 38.13 & 41.20 & 43.93 & 38.13 & 41.03 & 44.10 & 38.13 & 41.12 \\
\hline $\mathbf{N}_{9}$ & 5.45 & 6.11 & 5.78 & 5.64 & 7.46 & 6.55 & 5.55 & 6.78 & 6.16 & 33.97 & 29.80 & 31.89 & 34.57 & 30.33 & 32.45 & 34.27 & 30.07 & 32.17 & 39.80 & 36.00 & 37.90 & 39.80 & 36.00 & 37.90 & 39.80 & 36.00 & 37.90 \\
\hline $\mathrm{N}_{10}$ & 5.52 & 5.91 & 5.71 & 5.20 & 6.54 & 5.87 & 5.36 & 6.23 & 5.79 & 31.71 & 33.31 & 32.51 & 34.53 & 30.13 & 32.33 & 33.12 & 31.72 & 32.42 & 41.67 & 36.20 & 38.93 & 41.67 & 36.20 & 38.93 & 41.67 & 36.20 & 38.93 \\
\hline $\mathbf{N}_{11}$ & 4.21 & 4.31 & 4.26 & 4.65 & 4.84 & 4.75 & 4.43 & 4.58 & 4.50 & 37.52 & 35.87 & 36.69 & 37.27 & 36.77 & 37.02 & 37.39 & 36.32 & 36.85 & 55.20 & 54.13 & 54.67 & 56.53 & 56.13 & 56.33 & 55.87 & 55.13 & 55.50 \\
\hline$N_{12}$ & 5.24 & 6.59 & 5.91 & 5.64 & 6.34 & 5.99 & 5.44 & 6.47 & 5.95 & 31.10 & 30.84 & 30.97 & 31.60 & 32.07 & 31.83 & 31.35 & 31.45 & 31.40 & 39.73 & 39.15 & 39.44 & 40.73 & 37.47 & 39.10 & 40.23 & 38.31 & 39.27 \\
\hline $\mathbf{N}_{13}$ & 6.94 & 7.48 & 7.21 & 7.51 & 7.36 & 7.44 & 7.22 & 7.42 & 7.32 & 27.71 & 32.47 & 30.09 & 29.60 & 28.40 & 29.00 & 28.66 & 30.44 & 29.55 & 36.07 & 37.53 & 36.80 & 38.73 & 38.87 & 38.80 & 37.40 & 38.20 & 37.80 \\
\hline $\mathbf{N}_{14}$ & 5.33 & 6.19 & 5.76 & 5.40 & 6.94 & 6.17 & 5.37 & 6.57 & 5.97 & 32.37 & 31.76 & 32.07 & 32.13 & 32.27 & 32.20 & 32.25 & 32.02 & 32.13 & 45.00 & 43.93 & 44.47 & 45.00 & 43.27 & 44.13 & 45.00 & 43.60 & 44.30 \\
\hline $\mathbf{N}_{15}$ & 4.97 & 5.10 & 5.04 & 5.18 & 6.80 & 5.99 & 5.08 & 5.95 & 5.51 & 31.87 & 31.53 & 31.70 & 31.37 & 29.53 & 30.45 & 31.62 & 30.53 & 31.07 & 48.13 & 46.47 & 47.30 & 48.13 & 46.80 & 47.47 & 48.13 & 46.63 & 47.38 \\
\hline $\mathbf{N}_{16}$ & 4.35 & 4.87 & 4.61 & 4.95 & 5.48 & 5.22 & 4.65 & 5.18 & 4.91 & 36.27 & 36.12 & 36.20 & 36.93 & 36.33 & 36.63 & 36.60 & 36.23 & 36.42 & 53.07 & 54.38 & $\mathbf{5 3 . 7 2}$ & 54.20 & 54.60 & 54.40 & 53.63 & 54.49 & 54.06 \\
\hline \multirow[t]{2}{*}{ MEAN } & 5.19 & 5.77 & & 5.57 & 6.52 & & 5.38 & 6.14 & & 33.07 & 32.52 & & 33.28 & 32.11 & & 33.18 & 32.31 & & 46.01 & 45.67 & & 46.48 & 45.63 & & 46.24 & 45.65 & \\
\hline & $\begin{array}{l}\text { S.Em } \\
\pm\end{array}$ & \multicolumn{2}{|c|}{ C.D at $5 \%$} & $\begin{array}{l}\text { S.Em } \\
\pm\end{array}$ & \multicolumn{2}{|c|}{ C.D at $5 \%$} & $\begin{array}{c}\text { S.Em } \\
\pm\end{array}$ & \multicolumn{2}{|c|}{ C.D at $5 \%$} & $\begin{array}{c}\text { S.Em } \\
\quad \pm\end{array}$ & \multicolumn{2}{|c|}{ C.D at $5 \%$} & $\begin{array}{c}\text { S.Em } \\
\quad \pm\end{array}$ & \multicolumn{2}{|c|}{ C.D at $5 \%$} & $\begin{array}{c}\text { S.Em } \\
\pm\end{array}$ & \multicolumn{2}{|c|}{ C.D at $5 \%$} & $\begin{array}{c}\text { S.Em } \\
\pm\end{array}$ & \multicolumn{2}{|c|}{ C.D at $5 \%$} & $\begin{array}{c}\text { S.Em } \\
\pm\end{array}$ & \multicolumn{2}{|c|}{ C.D at $5 \%$} & $\begin{array}{c}\text { S.Em } \\
\pm\end{array}$ & \multicolumn{2}{|c|}{ C.D at $5 \%$} \\
\hline $\begin{array}{l}\text { Varieties } \\
\text { (V) }\end{array}$ & 0.01 & & 03 & 0.12 & & .39 & 0.07 & & .22 & 0.09 & 1 & & 0.14 & 0. & 44 & 0.10 & 0 . & 36 & 0.042 & & 52 & 0.109 & 0. & 67 & 0.049 & & 14 \\
\hline $\begin{array}{l}\text { Nutrients } \\
\text { (N) }\end{array}$ & 0.10 & & 20 & 0.32 & & .92 & 0.17 & & .49 & 0.63 & & 80 & 0.47 & 1. & 33 & 0.46 & 1. & 33 & 1.070 & 3. & 03 & 1.044 & 2. & 95 & 0.926 & & 62 \\
\hline $\begin{array}{c}\mathrm{N} \text { at } \\
\text { same } \mathrm{V}\end{array}$ & 0.25 & & IS & 0.46 & & vs & 0.24 & & NS & 0.90 & & 55 & 0.66 & 1. & 88 & 0.66 & 1. & 88 & 1.513 & 4 & 28 & 1.476 & 4. & 17 & 1.309 & & 70 \\
\hline $\begin{array}{c}\text { Vat same } \\
\text { or } \\
\text { different } \\
\mathbf{N}\end{array}$ & 0.21 & & NS & 0.50 & & NS & 0.28 & & NS & 0.43 & & 24 & 0.58 & 1. & 64 & 0.42 & 1. & 19 & 0.412 & & 16 & 0.562 & 1. & 59 & 0.379 & & 07 \\
\hline
\end{tabular}


Table.2 Growth parameters on leaf area index, tillers per plant and seed yield (q per ha) as influenced by Isabgol varieties and integrated nutrient management

\begin{tabular}{|c|c|c|c|c|c|c|c|c|c|c|c|c|c|c|c|c|c|c|c|c|c|c|c|c|c|c|c|}
\hline \multirow{3}{*}{$\begin{array}{l}\text { Varieties } \\
\text { Nutrients } \\
\text { Nutrients }\end{array}$} & \multicolumn{9}{|c|}{ leaf area index at harvest } & \multicolumn{9}{|c|}{ tillers per plant } & \multicolumn{9}{|c|}{ seed yield (q per ha) } \\
\hline & \multicolumn{3}{|c|}{2015} & \multicolumn{3}{|c|}{2016} & \multicolumn{3}{|c|}{ Pooled data } & \multicolumn{3}{|c|}{2015} & \multicolumn{3}{|c|}{2016} & \multicolumn{3}{|c|}{ Pooled data } & \multicolumn{3}{|c|}{2015} & \multicolumn{3}{|c|}{2016} & \multicolumn{3}{|c|}{ Pooled data } \\
\hline & $\mathbf{V}_{1}$ & $\mathbf{V}_{2}$ & Mean & $\mathbf{V}_{1}$ & $\mathbf{V}_{2}$ & Mean & $\mathrm{V}_{1}$ & $\mathbf{V}_{2}$ & Mean & $\mathbf{V}_{1}$ & $\mathbf{V}_{2}$ & Mean & $\mathrm{V}_{1}$ & $\mathbf{V}_{2}$ & Mean & $\mathbf{V}_{1}$ & $\mathbf{V}_{2}$ & Mean & $\mathbf{V}_{1}$ & $\mathbf{V}_{2}$ & Mean & $\mathbf{V}_{1}$ & $\mathbf{V}_{2}$ & Mean & $\mathbf{V}_{1}$ & $\mathbf{V}_{2}$ & Mean \\
\hline $\mathrm{N}_{1}$ & 2.51 & 2.37 & 2.44 & 2.53 & 2.41 & 2.47 & 2.52 & 2.39 & 2.45 & 9.60 & 9.02 & 9.31 & 9.80 & 9.93 & 9.87 & 9.70 & 9.48 & 9.59 & 12.05 & 9.43 & 10.74 & 12.93 & 9.62 & 11.27 & 12.49 & 9.52 & 11.01 \\
\hline $\mathbf{N}_{2}$ & 2.65 & 2.20 & 2.42 & 2.80 & 2.37 & 2.59 & 2.72 & 2.29 & 2.51 & 9.75 & 9.21 & 9.48 & 9.80 & 9.88 & 9.84 & 9.78 & 9.54 & 9.66 & 12.51 & 9.49 & 11.00 & 13.22 & 9.80 & 11.51 & 12.86 & 9.65 & 11.26 \\
\hline $\mathbf{N}_{3}$ & 2.66 & 2.59 & 2.62 & 2.80 & 2.66 & 2.73 & 2.73 & 2.62 & 2.68 & 9.15 & 9.05 & 9.10 & 9.73 & 9.63 & 9.68 & 9.44 & 9.34 & 9.39 & 11.79 & 11.85 & 11.82 & 12.43 & 12.14 & 12.28 & 12.11 & 11.99 & 12.05 \\
\hline $\mathbf{N}_{4}$ & 3.28 & 3.10 & 3.19 & 3.31 & 3.17 & 3.24 & 3.30 & 3.14 & 3.22 & 12.17 & 13.82 & 12.99 & 13.78 & 13.39 & 13.58 & 12.97 & 13.60 & 13.29 & 14.84 & 14.86 & 14.85 & 15.55 & 15.22 & 15.39 & 15.19 & 15.04 & 15.12 \\
\hline $\mathbf{N}_{5}$ & 2.46 & 2.51 & 2.48 & 2.54 & 2.61 & 2.58 & 2.50 & 2.56 & 2.53 & 9.81 & 9.98 & 9.90 & 9.67 & 9.47 & 9.57 & 9.74 & 9.73 & 9.73 & 10.56 & 10.49 & 10.53 & 10.89 & 10.58 & 10.73 & 10.72 & 10.54 & 10.63 \\
\hline$N_{6}$ & 3.32 & 3.17 & 3.25 & 3.49 & 3.24 & 3.37 & 3.41 & 3.21 & 3.31 & 12.39 & 12.25 & 12.32 & 13.95 & 14.23 & 14.09 & 13.17 & 13.24 & 13.20 & 14.87 & 14.81 & 14.84 & 15.29 & 14.34 & 14.82 & 15.08 & 14.57 & 14.83 \\
\hline $\mathbf{N}_{7}$ & 2.52 & 2.26 & 2.39 & 2.69 & 2.34 & 2.52 & 2.61 & 2.30 & 2.46 & 9.64 & 9.52 & 9.58 & 9.83 & 9.30 & 9.57 & 9.74 & 9.41 & 9.57 & 10.33 & 9.00 & 9.66 & 10.80 & 9.14 & 9.97 & 10.56 & 9.07 & 9.82 \\
\hline $\mathbf{N}_{8}$ & 2.65 & 2.16 & 2.41 & 2.75 & 2.29 & 2.52 & 2.70 & 2.23 & 2.46 & 9.60 & 9.17 & 9.38 & 9.53 & 9.30 & 9.42 & 9.57 & 9.23 & 9.40 & 10.14 & 9.38 & 9.76 & 10.29 & 8.62 & 9.45 & 10.21 & 9.00 & 9.61 \\
\hline $\mathbf{N}_{9}$ & 2.32 & 2.36 & 2.34 & 2.44 & 2.48 & 2.46 & 2.38 & 2.42 & 2.40 & 9.54 & 9.32 & 9.43 & 9.47 & 8.81 & 9.14 & 9.50 & 9.07 & 9.28 & 10.10 & 9.16 & 9.63 & 10.03 & 9.37 & 9.70 & 10.06 & 9.27 & 9.67 \\
\hline$N_{10}$ & 2.34 & 2.23 & 2.28 & 2.16 & 2.35 & 2.25 & 2.25 & 2.29 & 2.27 & 10.03 & 9.79 & 9.91 & 9.33 & 9.07 & 9.20 & 9.68 & 9.43 & 9.56 & 10.36 & 9.50 & 9.93 & 10.18 & 9.47 & 9.82 & 10.27 & 9.49 & 9.88 \\
\hline $\mathbf{N}_{11}$ & 3.38 & 3.35 & 3.36 & 3.64 & 3.34 & 3.49 & 3.51 & 3.34 & 3.43 & 13.96 & 13.03 & 13.50 & 14.85 & 13.91 & 14.38 & 14.41 & 13.47 & 13.94 & 15.34 & 15.22 & 15.28 & 15.66 & 15.53 & 15.59 & 15.50 & 15.37 & 15.43 \\
\hline $\mathbf{N}_{12}$ & 2.51 & 2.25 & 2.38 & 2.66 & 2.75 & 2.71 & 2.59 & 2.50 & 2.55 & 9.29 & 9.44 & 9.36 & 9.29 & 8.70 & 9.00 & 9.29 & 9.07 & 9.18 & 12.68 & 9.56 & 11.12 & 12.67 & 9.54 & 11.10 & 12.67 & 9.55 & 11.11 \\
\hline $\mathbf{N}_{13}$ & 2.15 & 1.91 & 2.03 & 2.31 & 2.68 & 2.50 & 2.23 & 2.29 & 2.26 & 8.03 & 8.76 & 8.40 & 8.13 & 9.00 & 8.57 & 8.08 & 8.88 & 8.48 & 9.95 & 8.37 & 9.16 & 9.96 & 8.71 & 9.33 & 9.95 & 8.54 & 9.25 \\
\hline $\mathbf{N}_{14}$ & 2.46 & 2.48 & 2.47 & 2.67 & 2.62 & 2.64 & 2.56 & 2.55 & 2.56 & 9.49 & 9.36 & 9.42 & 8.94 & 8.93 & 8.94 & 9.21 & 9.14 & 9.18 & 10.05 & 9.58 & 9.82 & 10.03 & 9.83 & 9.93 & 10.04 & 9.70 & 9.87 \\
\hline $\mathbf{N}_{15}$ & 2.34 & 2.79 & 2.56 & 2.67 & 2.85 & 2.76 & 2.51 & 2.82 & 2.66 & 9.95 & 9.34 & 9.65 & 8.94 & 8.77 & 8.85 & 9.44 & 9.06 & 9.25 & 14.65 & 10.88 & 12.77 & 12.70 & 11.18 & 11.94 & 13.68 & 11.03 & 12.35 \\
\hline $\mathrm{N}_{16}$ & 3.27 & 3.29 & 3.28 & 3.43 & 3.36 & 3.40 & 3.35 & 3.33 & 3.34 & 12.47 & 13.23 & 12.85 & 12.87 & 14.51 & 13.69 & 12.67 & 13.87 & 13.27 & 15.17 & 14.78 & 14.97 & 15.47 & 14.17 & 14.82 & 15.32 & 14.48 & 14.90 \\
\hline \multirow[t]{2}{*}{ MEAN } & 2.68 & 2.56 & & 2.81 & 2.72 & & 2.74 & 2.64 & & 10.30 & 10.27 & & 10.49 & 10.43 & & 10.40 & 10.35 & & 12.21 & 11.02 & & 12.38 & 11.08 & & 12.30 & 11.05 & \\
\hline & $\begin{array}{l}\text { S.Em } \\
\quad \pm\end{array}$ & \multicolumn{2}{|c|}{ C.D at 5\% } & $\begin{array}{l}\text { S.Em } \\
\pm\end{array}$ & \multicolumn{2}{|c|}{ C.D at $5 \%$} & $\begin{array}{l}\text { S.Em } \\
\pm\end{array}$ & \multicolumn{2}{|c|}{ C.D at $5 \%$} & $\begin{array}{l}\text { S.Em } \\
\quad \pm\end{array}$ & \multicolumn{2}{|c|}{ C.D at $5 \%$} & $\begin{array}{l}\text { S.Em } \\
\pm\end{array}$ & \multicolumn{2}{|c|}{ S.Em \pm} & $\begin{array}{c}\text { C.D } \\
\text { at } \\
\mathbf{5 \%}\end{array}$ & \multicolumn{2}{|c|}{ S.Em \pm} & $\begin{array}{c}\text { C.D } \\
\text { at } \\
\mathbf{5 \%}\end{array}$ & \multicolumn{2}{|c|}{ S.Em \pm} & $\begin{array}{c}\text { C.D } \\
\text { at } \\
\mathbf{5 \%}\end{array}$ & \multicolumn{2}{|c|}{ S.Em \pm} & $\begin{array}{c}\text { C.D } \\
\text { at } \\
\mathbf{5 \%}\end{array}$ & \multicolumn{2}{|c|}{ S.Em \pm} \\
\hline $\begin{array}{l}\text { Varieties } \\
\text { (V) }\end{array}$ & 0.067 & & vS & 0.046 & & NS & 0.056 & & NS & 0.03 & & $\mathbf{S}$ & 0.066 & & NS & 0.042 & 1 & & 0.16 & 0. & 49 & 0.08 & 0. & .24 & 0.09 & 0. & .29 \\
\hline $\begin{array}{l}\text { Nutrients } \\
\text { (N) }\end{array}$ & 0.087 & & .25 & 0.108 & & .31 & 0.088 & & .25 & 0.21 & & 60 & 0.200 & & .57 & 0.160 & 0 . & 45 & 0.36 & 1. & 04 & 0.35 & & .00 & 0.28 & & 79 \\
\hline $\begin{array}{c}\mathrm{N} \text { at } \\
\text { same } \mathrm{V}\end{array}$ & 0.123 & & NS & 0.153 & & NS & 0.125 & & NS & 0.29 & & 84 & 0.282 & & 80 & 0.226 & 0 . & 64 & 0.51 & 1. & 47 & 0.50 & & .41 & 0.39 & & .12 \\
\hline $\begin{array}{c}\text { Vat same } \\
\text { or } \\
\text { different } \\
\mathbf{N}\end{array}$ & 0.262 & & NS & 0.181 & & NS & 0.220 & & NS & 0.13 & & 39 & 0.265 & & .75 & 0.174 & 0. & 49 & 0.63 & 1. & 81 & 0.33 & 0 & .94 & 0.38 & & .07 \\
\hline
\end{tabular}


Interaction effect significantly higher seed yield (15.50 q ha ${ }^{-1}$ ) was recorded in Vallabh Isabgol-1 supplied of $\mathrm{N}_{11}$ (75\% RD of FYM + $75 \%$ of RD NPK + Azospirillum $+P S B+$ $\mathrm{ZnSO}_{4}+\mathrm{FeSO}_{4}$ ), which was on par with $\mathrm{V}_{2} \mathrm{~N}_{11}\left(15.37 \mathrm{q} \mathrm{ha}^{-1}\right), \mathrm{V}_{1} \mathrm{~N}_{16}\left(15.32 \mathrm{q} \mathrm{ha}^{-1}\right)$, $\mathrm{V}_{1} \mathrm{~N}_{4}\left(15.19 \mathrm{q} \mathrm{ha}^{-1}\right)$ and $\mathrm{V}_{1} \mathrm{~N}_{6}\left(15.08 \mathrm{q} \mathrm{ha}^{-1}\right)$. The lower seed yield $\left(8.54 \mathrm{q} \mathrm{ha}^{-1}\right)$ was recorded in $\mathrm{V}_{2} \mathrm{~N}_{13}$ during pooled data. This increased yield parameters due to use of improved variety because of genotypic character and increased the growth parameters conversion towards yield parameters with integrated use of chemical fertilizer, manures like FYM enhances the uptake of $\mathrm{N}, \mathrm{P}$ and $\mathrm{K}$ by process releasing humus forming microbes, Azotobactor has nitrogen fixing potential as Nitrogenase activity of rhizosphere in soils by releasing some growth regulators IAA, results in the production of more vegetative growth parameters conversion towards physiological then reproductive. This relationship helped to increase the yield attributes, this leads to increase the straw yield and biological yield of Isabgol ultimately, these characters had positive beneficial effect towards higher seed yield same findings revealed by Hindiholi et al., (2006), Chaudhary and Shivran et al., (2009), Saxena and Rao (2009), Shivran et al., (2015) and Shivran et al., (2016a).

\section{References}

Anonymous, 2015a, Annual Report, DMAPR, Anand, p.43-45.

Anonymous, 2015b, Horticultural statistics at a glance, state-wise estimates of output from Agriculture and Allied Activities, CSO, MOSPI: 96.

Choudhary, I. and Shivran, A. C., 2009, Effect of integrated nutrient management on yield quality and nutrient uptake of Isabgol. Ann. Agric. Res. New Series, 30 (3 and 4): 105-107.

Choudhary, T., Sharma, S. K. and Yadav, B. K., 2014, Influence of FYM and inorganic fertilizers on growth and yield of Isabgol
(Plantago ovata Forsk.). J. Spices Aromatic Crops, 23 (1): 130-136.

Dubey, R. B., Jain, S. K. and Maloo, S. R., 2009, Genetic divergence in Isabgol (Plantago ovata Forsk.). J. Spices and Aromatic Crops, 31(1): 29-32.

Ghaderi-Far, F., Alimagham, S. M., Kameli, A. M. and Jamali, M., 2012, Isabgol (Plantago ovata Forsk.) seed germination and emergence as affected by environmental factors and planting depth. Intl. J. Pl. Production., 6 (2): 185194.

Hindiholi, M.S., Kattimani, K.N. and Devendrappa, S., 2007, Effect of dates of sowing and nitrogen levels on growth and yield of Isabgol (Plantago ovata Forsk.). Nat. Sem. Prod., Processing and Marketing of Med. Dye Yielding Crops, 22-23 February, KRCCH, Arabhavi, Karnataka, pp. 37.

Kumar, S. R., Beniwal., B. R. and Choudhary. B. R., 2009, A high yielding Isabgol (Plantago ovata Forsk.) genotype for arid western plain of Rajasthan. Annals of Arid Zone, 48(2): 169-170.

Mirshekari, S. and Forouzandeh, M., 2015, Analysis of effect of organic fertilizer on yield and active substance of Psyllium herbal plant (Plantago ovata L.). Biological Forum - An Intl. J., 7(1): 436-440.

Nadim, M, M., Ahmad, J., Umer, S. and Bakshi, S.K., 2011, Influence of nutrients and microorganisms on the growth and yield of (Plantago ovata Forsk.). Trends in Biosciences, 4 (2): 169-171.

Nadukeri, S., Kattimani, K. N. and Kolakar, S. S., 2014, Influence of organic and inorganic fertilizers on growth and tuber yield of Coleus (Coleus forskohlii Briq.) under northern dry zone of Karnataka. Intl. J. Agric. Sci., 10 (1): 119-123.

Patel, A., and Saravanan, R., 2010, Screening of plantago species for physiological parameters in relation to seed yield. Electronic J. Plant Breeding, 1(6):14541460.

Repsiene, R., 2001, Efficiency of placement 
fertilization for barley yield in conservation agriculture a worldwide Challenge. First World Congress on Conservation agriculture; Madrid, Spain, 2: 327-330.

Salmasi, S, Z., Behrouznajhad, S. and Golezani, K. G., 2012, Effects of foliar application of $\mathrm{Fe}$ and $\mathrm{Zn}$ on seed yield and mucilage content of Psyllium at different Stages of maturity. International Conference on Environment, Agriculture and Food Sciences. (ICEAFS'), Phuket, Thailand.

Saxena, A. and Rao, A. V., 2000, Response of Isabgol to aztobacter inoculation under field condition in arid zone. Annals of Arid Zone, 39(2): 199-201.

Sharma, K., Dak, G., Agrawal, A., Bhatnagar, M. and Sharma, R., 2007. Effect of phosphate solubilizing bacteria on germination of Cicer arietinum seeds and seedling growth. Journal of Herbal Medicine and Toxicology. 1:61-63.

Shivran, A. C., 2016a, Response of bond Psyllium (Plantago ovata Forsk.) varieties to time of sowing and nitrogen fertilization under semi-arid condition. Intl. J. Seed Spices., 6 (2): 50-54.

Shivran, A. C., 2016b, Growth yield and nutrient uptake of Isabgol (Plantago ovata Forsk.) with phosphorus PSB and zinc fertilization. Intl. J. Seed Spices, 6 (1): 66-73.

Shivran, A. C., Yadav, S. S., Sharma, O. P.,
Yadav, L. R., Dudwal, B. L. and Meena. O. P., 2015, Response of phosphorus phosphate solubilizing bacteria and zinc on yield and quality of blond Psyllium (Plantago ovata Forsk.). Intl. J. Seed Spices., 5(2): 49-54.

Singh., S.B., Chauhan. and Vishwanath, 2011, Evaluation of Isabgol (Plantago ovata Forsk.) varieties to potash levels in semiarid condition. The J. Rural \& Agric. Res., (2): 58-59.

Tripathi, V. K., Sanjeev Kumar, Katiyar, P. N. and Nayyer, M.A., 2013, Integrated nutrient management in Isabgol (Plantago ovata Forsk.). Progressive Horticulture, 45: 302-305.

Tyagi, S., Singh, O. P., Kumar, A., Sahay, S., Nanher, A, H. and Mishra, P, K., 2016, Studies on the performance of Isabgol (Plantago ovata Forsk.) genotypes under uttar pradesh condition. Research Environ. life. Sci., 9 (10): 1239-1241.

Venkatesh, N.T. 2007, Integrated nutrient management in Isabgol (Plantago ovate Forsk.). M.Sc (Horti)Thesis, UAS Dharwad.

Yadav, R.D., Keshwa, G.L. and Yadav, S. S., 2003, Effect of integrated use of FYM, urea and sulphur on growth and yield of Isabgol (Plantago ovata Forsk.). $J$. Medicinal and Aromatic Plants Sci., 25: 668-671.

\section{How to cite this article:}

Siddalingayya V. Salimath, K. N. Kattimani, Y. K. Kotikal, D. R. Patile, Md Jameel Jhalegar, J. Venkatesh and Nagarja, N. S. 2019. Influence of Varieties and Integrated Nutrient Management on Growth Parameters of Isabgol (Plantago ovata Forsk.) under Northern Dry Zone of Karnataka. Int.J.Curr.Microbiol.App.Sci. 8(09): 2005-2013. doi: https://doi.org/10.20546/ijcmas.2019.809.232 